\title{
Zlepší nová účetní směrnice účetní výkaznictví v Evropě?
}

Vážení čtenáři,

evropské finanční účetnictví a výkaznictví je již více než třicet let regulováno účetními směrnicemi, jmenovitě Čtvrtou a Sedmou směrnicí (78/660/EEC a 83/349/EEC). Směrnice byly sice od svého vydání několikrát novelizované, ale nebyly podrobeny zásadní a systematické revizi. Zavedly se nové požadavky na účetní výkaznictví, např́klad pravidla zveřejňování a oceňování, zavedlo se oceňování v reálných hodnotách. Nově zavedené požadavky na účetní výkaznictví však ze směrnic udělaly pravidla, která se léty stala nesrozumitelná a tudíž pro účetní jednotky i obtížně realizovatelná. Směrnice pro různé oblasti účetnictví nebyla koncipována stejně a lišila se různým stupněm jejich podrobností. Směrnice navíc obsahovaly více možností, které účetní pravidlo ze směrnice použít pro konkrétní případ, lišily se i účetní metody. Tato možnost volby ve svém důsledku způsobila obtížnosti při porovnávání informací z účetních závěrek sestavených podle domácích pravidel různých členských států. Jak vyplývá z různých analýz a výzkumných projektů, jako např́ḱlad „Sdělení o zjednodušení podnikovém prostředí pro společnosti v oblastech obchodního práva, účetnictví a auditingu“ nebo projektu zaměřeného na vyčíslení administrativních nákladů a jejich snížení, věnovalo se méně pozornosti skutečnosti, zdali existující požadavky v oblasti účetního výkaznictví by se měly odstranit nebo zjednodušit. Zmíněné studie potvrzují, že úpravy směrnic a zavedení nových požadavků na výkaznictví mají sklon ignorovat srovnatelnost a užitečnost účetních výkazů a zvyšují požadavky na výkaznictví a počet voleb, které zavádějí členské státy. Všechny tyto skutečnosti vedly v dlouhodobém měřítku ke zvýšení složitosti a administrativní náročnosti pro všechny společnosti. Jak potvrzuje jiné sdělení Evropské komise z roku 2008, krátce označované jako „Mysli nejdříve na malé podniky“, toto zvýšené administrativní břemeno doléhá především na malé podniky. Strategie „Evropa 2020“, kromě úsilí o vybudování takového systému ekonomiky v Evropské unii, který bude systémem trvale udržitelným, má za cíl zjednodušit život malých a středních podniků, které představují více jak 99 \% všech evropských podniků, a zlepšit přístup těchto společností $\mathrm{k}$ financím.

Členské státy stále více upozorňovaly na nutnost zlepšit regulaci finančního účetnictví a výkaznictví tak, aby došlo k lepší srovnatelnosti účetních informací na úrovni Evropské unie. Práce na modernizaci, zlepšení a vyšší srozumitelnosti směrnic začaly před několika lety a byly dovršeny tento rok ve formě nově vydané směrnic. Směrnice 2013/34/EU Evropského parlamentu, zveřejněná Evropskou unií, se týká ročních účetních závěrek a konsolidované účetní závěrky. Nová směrnice respektuje ve svém znění ustanovení Směrnice Evropského parlamentu a Rady 2006/43/EC a nahrazuje Čtvrtou a Sedmou směrnici Rady. Nová směrnice vymezuje malý, střední a velký podnik podle vžité praxe odlišením těchto kategorií podniků v závislosti na čistém obratu, bilanční sumě a počtu zaměstnanců. Navíc do nové směrnice je zakomponována Směrnice 2012/6/EU o mikrosubjektech, která umožňuje těmto účetním jednotkám sestavovat velmi jednoduchou rozvahu a výsledovku s prakticky nulovou př́lohou k účetní závěrce. 
Směrnice rovněž zjednodušuje pravidla pro sestavení účetní závěrky malých podniků a konsolidovanou účetní závěrku malých podniků snížením a omezením množství informací poskytnutých $\mathrm{v}$ prríloze $\mathrm{k}$ účetní závěrce. Některé změny jsou zejména pro malé podniky méně restriktivní. Nicméně pro střední podniky a velké podniky nebo skupiny velkých podniků, stejně tak i pro subjekty veřejného zájmu, by mohly být změny, jako jsou události po datu účetní závěrky, více omezující. Mezi další klíčové změny, které byly zavedeny v nové směrnici, patří: princip významnosti (agregace účetních informací v účetních výkazech, pokud je taková informace považována za nevýznamnou); rozšîření definice vlivu; potenciální výjimky konsolidace pro skupiny středních podniků (s výjimkou subjektů veřejného zájmu). Účetní požadavky jsou zjednodušeny a zmenšeny pro malé a střední podniky, které nejsou veřejně obchodované. Zjednodušené nebo zmírněné požadavky na výkaznictví se netýkají subjektů veřejného zájmu.

Kromě kategorizace podniků a vysvětlujících definic, směrnice určuje, že roční účetní závěrka je u všech podniků tvořena přinejmenším rozvahou, výsledovkou a přílohou k účetní závěrce. Směrnice naopak nepožaduje sestavení výkazu o peněžních tocích. Další výkazy lze požadovat u všech podniků kromě těch malých. Roční účetní závěrka musí podávat věrný a poctivý obraz o aktivech, pasivech, finanční situaci a výsledku hospodaření podniku. Výjimka $\mathrm{z}$ tohoto pravidla je pouze $\mathrm{v}$ př́padech, kdy uplatňování některého ustanovení této směrnice je neslučitelné s povinností podávat věrný a poctivý obraz. Nepoužití věrného a poctivého obrazu se musí uvést v př́loze.

Spojení Čtvrté a Sedmé směrnice bylo s ohledem na množství vzájemných odkazů logickým krokem. Navíc během diskusí se zástupci členských států a veřejností došlo k výrazné podpoře takových opatření, která by vedla $\mathrm{k}$ větší srozumitelnosti a stálosti účetního rámce především pro podniky, které nejsou obchodované na burzách. Vzhledem k tomu, že většina členských států již do své legislativy přijala výjimku umožňující malým skupinám nesestavovat konsolidovanou účetní závěrku, byla směrnice potvrzením tohoto přístupu a osvobodila malé skupiny od sestavování konsolidované účetní závěrky.

Nová směrnice se výrazně odlišuje od původních směrnic, především svojí filozofií, zavedením specifického režimu pro malé podniky, aby došlo k výraznému snížení administrativní náročnosti při sestavování účetní závěrky. S malými podniky se, v souladu se směrnicí, má v celé EU zacházet stejným způsobem, aby došlo k využití výhody z možnosti př́stupu k jednotnému trhu s homogenními podmínkami. Členské státy by neměly uvalit na podniky dodatečné požadavky, a tím by mělo dojít ke snížení administrativní zátěže i zabezpečení souladu s komunitárním právem.

doc. Ing. Marcela Žárová, CSc.

proděkanka pro zahraniční vztahy

Fakulta financí a účetnictví

Vysoká škola ekonomická v Praze 